\title{
Genetic variability in storage root bulking of cassava genotypes under irrigation and no irrigation
}

\author{
Joseph Adjebeng-Danquah 1,3* ${ }^{\text {, Vernon Edward Gracen }}{ }^{2,3}$, Samuel Kwame Offei ${ }^{3}$, Isaac Kwadwo Asante 3,4 \\ and Joseph Manu-Aduening ${ }^{5}$
}

\begin{abstract}
Background: Early bulking in cassava (Manihot esculenta Crantz) is a very important trait in semi-arid ecologies of the tropics. Farmers tend to select early-maturing cassava varieties to escape terminal drought and destruction by domestic animals during the dry season. However, early harvesting is associated with yield penalty due to unavailability of high-yielding early-maturing cassava varieties. In order to develop early-bulking cassava varieties for the savanna ecologies, this study was carried out to assess genetic variation in the pattern of storage root bulking and as well as traits associated with early storage root bulking under moisture stress and well-watered conditions.
\end{abstract}

Methods: Twenty cassava genotypes were arranged in a randomised complete block design with three replications under irrigation and no irrigation. The genotypes were sequentially harvested at 6, 8, 10 and 12 months after planting to study their pattern of dry matter accumulation. Irrigation water was supplied using a drip irrigation system with a discharge capacity of $1.6 \mathrm{l} / \mathrm{h}$.

Results: Analysis of variance indicated significant effect of genotype, harvesting time and irrigation on most of the yield traits studied. The interaction between genotype and irrigation effect was significant for all traits except mean storage root weight, storage root girth, storage root length and storage root dry matter content. Apart from storage root girth and storage root dry matter content, genotype $\times$ harvesting time interaction was not significant. Pearson correlation analysis of root yield at different times showed significant positive correlation between early storage root yield and final root yield indicating the possibility of selecting early-bulking genotypes with high yield potential.

Conclusion: The study indicated that dry matter is partitioned more for root elongation than expansion in root girth under moisture stress conditions compared with irrigation, resulting in high storage root length: girth ratio. This ratio can be used to study the pattern of photosynthates accumulation in cassava roots under stress conditions. The study helped to provide improved understanding of the genetic basis and the mechanism of storage root bulking in cassava under moisture stress conditions, which can be exploited to develop high-yielding cassava varieties for droughtprone areas to ensure food security.

Keywords: Cassava (Manihot esculenta Crantz), Early bulking, Moisture stress, Photosynthates accumulation, Storage root length: girth ratio

\section{Background}

Cassava (Manihot esculenta Crantz) has the ability to grow in marginal ecologies where other crops fail $[1,2]$.

\footnotetext{
*Correspondence: barchus2003@yahoo.com

${ }^{1}$ CSIR-Savanna Agricultural Research Institute, P. O. Box TL 52, Tamale, Ghana

Full list of author information is available at the end of the article
}

In the tropics, the starchy roots provide a major staple for millions of people, especially rural dwellers [3, 4]. Several studies have attributed cassava's ability to grow in these ecologies to its hardiness and ability to tolerate dry conditions through enhanced water-use efficiency [1, 4, 5]. Many cassava varieties are drought tolerant, resistant to

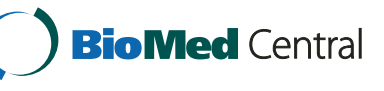

(C) 2016 The Author(s). This article is distributed under the terms of the Creative Commons Attribution 4.0 International License (http://creativecommons.org/licenses/by/4.0/), which permits unrestricted use, distribution, and reproduction in any medium, provided you give appropriate credit to the original author(s) and the source, provide a link to the Creative Commons license, and indicate if changes were made. The Creative Commons Public Domain Dedication waiver (http://creativecommons.org/ publicdomain/zero/1.0/) applies to the data made available in this article, unless otherwise stated. 
most diseases and pests and can survive in harsh environments [6].

Cassava is naturally a perennial shrub but has been grown for its starchy roots on annual basis $[2,7,8]$. The duration of the crop depends on the growing conditions and the environment $[8,9]$. Wahid et al. [10], however, indicated that plant responses to environmental stress vary and depend on the species and phenological stages. Partitioning of dry matter is directed either towards shoot production or root production depending on the environmental conditions [4, 7]. This has led to different times of maturity for different cassava genotypes with some maturing earlier than others [11, 12]. For instance, it is harvested early in hot humid climates but grown for up to 2 years in cooler or drier areas. These hot and dry environments are often characterised by $4-5$ months of rainy season followed by a long dry season lasting up to 7 months. Farmers therefore adopt crop varieties that fit into the short growing season. According to AnnorFrempong [13], early maturity was the most frequent attribute desired by farmers in the transitional ecological zone of Ghana. Several studies have revealed that late bulking is the single most important reason for the rejection and abandonment of cassava varieties in African countries [13-16]. Late-bulking cultivars occupy land for extended periods of time, and consequently the land cannot be effectively utilised for the sequential cultivation of other crops.

Early storage root yield (bulking) in cassava has also been identified as a very important trait in drought tolerance $[14,17]$. In some cases, earliness enables escape from late season droughts, pests and diseases and is perceived as a key control strategy for cassava brown streak disease (CBSD), which is currently epidemic in east, central and southern Africa $[8,16,18,19]$. It is also important in situations where pressure on agricultural lands forces farmers to intensify production and harvest their crops after only one cycle of rain, particularly in semiarid regions. However, extreme earliness comes with a yield penalty due to a reduction in the period of dry matter accumulation [19]. Varietal selection, if done carefully, will be useful in identifying cassava varieties which partition dry matter into the storage roots at an earlier stage in order to minimise the yield loss due to early harvesting.

Efforts to develop early-bulking cassava varieties have been hampered by the absence of distinct indicators of the trait in cassava. Though Alves [7] reported that storage root bulking in cassava begins after sufficient shoot growth has occurred, Okogbenin and Fregene [11] suggested that certain cassava varieties undergo shoot growth and storage root bulking simultaneously. The efficiency of partitioning carbohydrates into shoots and storage roots depends on environmental conditions that influence storage root growth. Under deficit moisture, root growth continues, whereas shoot growth is limited, resulting in higher root-to-shoot ratio [20]. This arises as a result of selective allocation of photosynthates below the soil surface to permit greater exploration of soil moisture while preventing water loss through the shoots [21]. Thus, most drought-tolerant crop varieties have been associated with deep root system and high root densities in addition to stomatal sensitivity to low moisture in the air in the case of cassava $[2,5,22]$. However, there is limited information on the relationship between these structural adaptations for drought tolerance and productivity in terms of storage root yield in cassava. This calls for an in-depth study into the relationship between the growth pattern of storage roots and productivity in cassava under limited moisture and well-watered conditions to assess the pattern on dry matter accumulation. Careful exploitation of the reported genetic variation in the rate and pattern of accumulation of dry matter in the storage roots $[17,23]$ has to be made to develop early-bulking cassava varieties with acceptable yields in savannah ecologies.

The aim of this study was to assess the genetic variability in storage root bulking under limited moisture and well-watered conditions.

Specific objectives were to:

1. determine genetic variation in storage root bulking

2. identify traits associated with early storage root bulking in cassava

3. determine the relationship between early dry matter accumulation in storage roots and final storage root yield.

\section{Methods}

\section{Study site}

The experiment was carried out at the CSIR-Savanna Agricultural Research Institute located at Nyankpala $\left(9^{\circ} 25^{\prime} \mathrm{N}, 0^{\circ} 58^{\prime} \mathrm{W}\right)$ in the Guinea Savannah agro-ecological zone of Ghana. The Guinea Savannah zone covers over $40 \%$ of the entire land area of Ghana and is characterised by high temperatures and low humidity for most parts of the year [24]. The rainfall pattern is monomodal and erratic with an annual mean of $1100 \mathrm{~mm}$, which usually begins in April-May and ends in October. The area is also characterised by a long dry season (4-5 months), which normally begins in November and lasts till April. Intermittent dry spells, often lasting up to 2 weeks, also occur during the rainy season.

\section{Germplasm and planting materials used for the study}

Twenty cassava genotypes obtained from local and exotic sources were evaluated in this study. The genotypes were 
selected based on storage root yield, storage dry matter content, harvest index and plant height in an earlier preliminary evaluation trial. They included six local landraces collected from farmers' fields, seven drought-tolerant genotypes collected from the International Institute of Tropical Agriculture (IITA) and seven varieties from the International Center for Tropical Agriculture (CIAT), Colombia.

\section{Land preparation, experimental design and planting}

The land was first slashed, ploughed and harrowed. The experiment was then laid out in a randomised complete block design with three replications in each of the irrigated and the no irrigation trials. Ridges were manually raised using a spacing of $1 \mathrm{~m}$ between adjacent ridges. Good quality cassava cuttings measuring $25-30 \mathrm{~cm}$ were planted on the top of ridges using within row spacing of $1 \mathrm{~m}$. A plot consisted of four rows per genotype with 10 plants in a row. No fertiliser was applied to the trials, but weeds were controlled as and when necessary. Reshaping of ridges was done to prevent exposure of the roots.

\section{Irrigation water application}

During the dry season, irrigation was applied using a drip irrigation system until the rains began the following season. Drip holes spaced at $30-\mathrm{cm}$ interval on each line had a discharge capacity of $1.6 \mathrm{l} / \mathrm{h}$. This gave a discharge rate of $5.33 \mathrm{l} / \mathrm{m}^{2} / \mathrm{h}$. Water was supplied twice a week for $4 \mathrm{~h}$ each day until May 2014 when the rains stabilised.

The irrigation commenced when visible signs of moisture stress appeared on the plants. No irrigation was applied to drought-stressed plots.

\section{Data collection}

\section{Fresh storage root yield ( $t / h a$ ) and yield components}

Four sequential harvests were done at 6, 8, 10 and 12 months after planting (MAP) under both irrigation and no irrigation. At each harvest, number of storage roots per plant was recorded. Ten roots were purposefully selected from four plants and measured from one tip to the other with a tape to determine storage root length $(\mathrm{cm})$. Storage root girth $(\mathrm{cm})$ was also determined by measuring the widest portion of the same roots using vernier callipers. Storage root length: girth ratio was also calculated to determine the pattern of dry matter accumulation in the storage roots, for extension or expansion. Mean storage root weight $(\mathrm{g})$ was determined from the weight of storage roots divided by the total number of storage roots harvested from each plot.

\section{Storage root dry matter content}

Storage roots were first chopped into pieces (about $1 \mathrm{~cm}$ thick) and mixed thoroughly. Afterwards, $100 \mathrm{~g}$ of each sample was taken and dried at $80{ }^{\circ} \mathrm{C}$ for $48 \mathrm{~h}$ and weighed. Percentage dry matter content was obtained by expressing the dry weight as a percentage of the fresh weight of the sample taken.

\section{Harvest index}

Harvest index was estimated as the ratio of the storage root weight to the total biomass weight (shoots plus storage roots).

\section{Data analysis}

General analyses of variance were performed for all traits using the GenStat statistical package [25]. Irrigation and harvesting times were considered as fixed factors, whilst genotypes were considered as random factor. To estimate genotypic variability in storage root yield at different times under irrigation and no irrigation, harvest time, genotypes and their interactions were considered as independent factors. Pearson's correlation was used to determine relationships between storage root yield at different times and final storage root yield at 12 months after planting. Two sample $t$ tests were performed to compare the mean performance of all genotypes under irrigation and no irrigation using the GenStat version $12.1[25]$.

\section{Results}

\section{Weather conditions during the period of the experiment}

Total rainfall recorded over the experimental period was $1181.1 \mathrm{~mm}$, whilst the evaporation was $1823.26 \mathrm{~mm}$ (Table 1). In addition, a total of $853.3 \mathrm{~mm}$ of water was applied to the irrigated plots. This gave a total quantity of $2034.43 \mathrm{~mm}$ of water for use by the plants under irrigation. Monthly fluctuations in rainfall, evaporation, relative humidity and temperature were observed during the study (Fig. 1). The highest amount of rainfall $(217.4 \mathrm{~mm})$ was recorded in August 2013, whilst no rain was recorded in December 2013 and January 2014. Average minimum temperature and maximum temperature for the entire season were 24.16 and $33.67{ }^{\circ} \mathrm{C}$, respectively, with a mean of $28.71{ }^{\circ} \mathrm{C}$. The highest monthly temperature is $37.5^{\circ} \mathrm{C}$ that was recorded in March 2014, which also had an evaporation of $223.32 \mathrm{~mm}$. There were fluctuations in the distribution of rainfall and evaporation. Monthly evaporation exceeded rainfall from November 2013 to May 2014. Relative humidity also declined from September 2013 to February 2014 before it started to rise again. Temperature fluctuations were also observed over the period of the experiment.

\section{Analyses of variance for storage root yield and yield components}

Highly significant $(\mathrm{P}<0.001)$ genotype and irrigation treatment effects were observed for storage root yield ( $\mathrm{t} /$ 
Table 1 Total water and evaporation under irrigation and no irrigation

\begin{tabular}{lcc}
\hline & Irrigation & No irrigation \\
\hline Irrigation water applied $(\mathrm{mm})$ & 853.33 & 0.00 \\
Amount of rainfall $(\mathrm{mm})$ & 1181.1 & 1181.10 \\
Total water supplied & 2034.43 & 1181.10 \\
Evaporation $(\mathrm{mm})$ & 1823.26 & 1823.26 \\
\hline
\end{tabular}

ha) and all yield components (Table 2). With the exception of number of storage roots per plant, harvest time had highly significant effect $(\mathrm{P}<0.001)$ on storage root yield and yield components. Genotype by irrigation effect was highly significant $(\mathrm{P}<0.001)$ on storage root yield $(\mathrm{t} /$ ha) and very significant $(\mathrm{P}<0.01)$ for harvest index and significant $(\mathrm{P}<0.05)$ for number of storage roots per plant. However, its effect on mean storage root weight (g), storage root length $(\mathrm{cm})$ and storage root dry matter content was not significant $(P>0.05)$. Interaction of genotype and harvest time effect was insignificant $(\mathrm{P}>0.05)$ for yield and all yield components except storage root girth and dry matter content. Three-way interaction of genotype by irrigation by harvest time effect for all the root yield and yield components was not significant $(\mathrm{P}>0.05)$.

\section{Relationship among traits}

Pearson correlation analysis indicated significant associations between most of the traits and storage root yield (Table 3). Storage root yield was positively correlated with all the traits except storage root length: girth ratio and storage root dry matter content, which were negative. The strongest correlated variable was storage root girth $(\mathrm{r}=0.78)$, which was followed by mean storage root weight $(r=0.69)$, storage root length $(r=0.36)$,

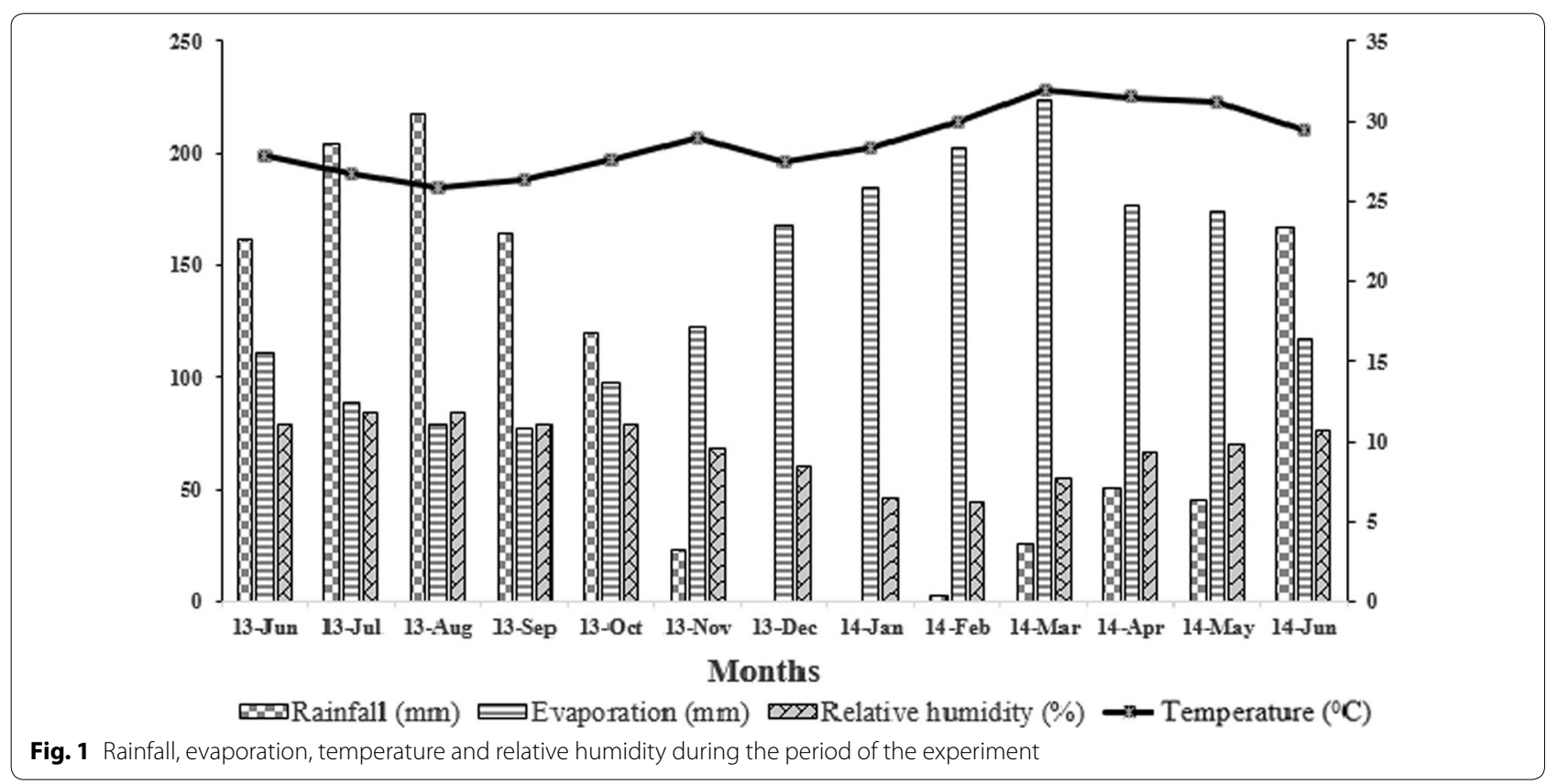

Table 2 Mean squares for storage root yield and yield components

\begin{tabular}{|c|c|c|c|c|c|c|c|c|c|}
\hline Source of variation & Df & Rt_yld (t/ha) & $\mathrm{HI}$ & MRW (g) & Rt_girth [G] (cm) & Rt_length [L] (cm) & L/G ratio & Rt_no/plt & $\mathrm{DM} \%$ \\
\hline Genotype (G) & 19 & $195.86^{* * *}$ & $0.094^{* * *}$ & $47741^{* * *}$ & $5.61^{* * *}$ & $443.69^{* * *}$ & $69.73^{* * *}$ & $37.29 * * *$ & $140.18^{* * *}$ \\
\hline Irrigation (I) & 1 & $2047.91^{* * *}$ & $0.039^{* * *}$ & $269826^{* * *}$ & $93.69^{* * *}$ & $3235.29 * * *$ & $1389.10^{* * *}$ & $192.22^{* * *}$ & $87.85^{* * *}$ \\
\hline Harvest time $(\mathrm{H})$ & 3 & $2705.53^{* * *}$ & $0.216^{* * *}$ & $392571^{* * *}$ & $143.83^{* * *}$ & $3709.37^{* * *}$ & $156.79^{* * *}$ & $3.40 \mathrm{NS}$ & $880.85^{* * *}$ \\
\hline Gxl & 19 & $23.91^{* * *}$ & $0.007^{* *}$ & 6158NS & $0.72^{* * *}$ & 33.39NS & $9.61^{* *}$ & $8.04^{*}$ & $10.52 \mathrm{NS}$ \\
\hline $\mathrm{GxH}$ & 57 & $12.01 \mathrm{NS}$ & $0.003 \mathrm{NS}$ & $3757 N S$ & $1.13^{* * *}$ & $32.85 \mathrm{NS}$ & $4.72 \mathrm{NS}$ & $3.02 \mathrm{NS}$ & $11.96^{* *}$ \\
\hline GxIxH & 57 & $6.99 \mathrm{NS}$ & $0.003 \mathrm{NS}$ & $4471 N S$ & $0.68 \mathrm{NS}$ & $34.52 \mathrm{NS}$ & $4.54 \mathrm{NS}$ & $2.98 \mathrm{NS}$ & $7.764 \mathrm{NS}$ \\
\hline Error & 308 & 9.21 & 0.003 & 3881.00 & 0.60 & 33.40 & 4.11 & 4.86 & 7.46 \\
\hline
\end{tabular}

*,****** $\mathrm{P}<0.05, \mathrm{P}<0.01$, and $\mathrm{P}<0.001$, NS Not significant $(\mathrm{P}>0.05)$. Rt_yld ( $\mathrm{t} / \mathrm{ha})$, storage root yield (t/ha); Hl, harvest index; MRW (g), mean storage root weight ( $g$ ); Rt_girth $(\mathrm{cm})$, storage root girth $(\mathrm{cm})$; Rt_length $(\mathrm{cm})$, storage root length $(\mathrm{cm})$; L/G ratio, storage root length: girth ratio; Rt_no/plt, number of storage roots per plant; $\mathrm{DM} \%$, storage root dry matter content (\%) 
Table 3 Correlation among storage root yield and other yield components

\begin{tabular}{|c|c|c|c|c|c|c|c|c|c|}
\hline & & 1 & 2 & 3 & 4 & 5 & 6 & 7 & 8 \\
\hline Rt_yld (t/ha) & 1 & - & & & & & & & \\
\hline $\mathrm{HI}$ & 2 & $0.18^{* * *}$ & - & & & & & & \\
\hline MRW (g) & 3 & $0.69^{* * *}$ & $0.32^{* * *}$ & - & & & & & \\
\hline Rt_girth [G] (cm) & 4 & $0.78^{* * *}$ & $0.13^{* *}$ & $0.71^{* * *}$ & - & & & & \\
\hline Rt_length [L] (cm) & 5 & $0.36^{* * *}$ & $0.09 \mathrm{NS}$ & $0.40^{* * *}$ & $0.29 * * *$ & - & & & \\
\hline L/G ratio & 6 & $-0.45^{* * *}$ & $-0.02 \mathrm{NS}$ & $-0.37^{* * *}$ & $-0.62^{* * *}$ & $0.45^{* * *}$ & - & & \\
\hline Rt_no/plt & 7 & $0.24^{* * *}$ & $-0.16^{* * *}$ & $-0.26^{* * *}$ & $0.05 \mathrm{NS}$ & $-0.08 \mathrm{NS}$ & $-0.09^{*}$ & - & \\
\hline DM \% & 8 & $-0.28^{* * *}$ & $0.04 \mathrm{NS}$ & $-0.15^{* * *}$ & $-0.26^{* * *}$ & $-0.30^{* * *}$ & $0.11^{*}$ & $-0.03 \mathrm{NS}$ & - \\
\hline
\end{tabular}

******* $\mathrm{P}<0.05, \mathrm{P}<0.01$, and $\mathrm{P}<0.001$, NS not significant $(\mathrm{P}>0.05)$. Rt_yld (t/ha), storage root yield (t/ha); $\mathrm{AGB}$ ( $\mathrm{t} / \mathrm{ha})$, above ground biomass (t/ha); HI, harvest index; MRW (g), mean storage root weight $(\mathrm{g})$; Rt_girth $(\mathrm{cm})$, storage root girth $(\mathrm{cm})$; Rt_length $(\mathrm{cm})$, storage root length $(\mathrm{cm})$; L/G ratio, storage root length: girth ratio; $\mathrm{Rt} \_$no/plt, number of storage roots per plant; DM\%, storage root dry matter content (\%)

storage root number per plant $(r=0.28)$ and harvest index $(r=0.18)$. The correlation between storage root yield and storage root girth $(r=0.78)$ was stronger than between root yield and root length $(r=0.36)$. Root length to girth ratio had negative correlation with most of the traits that were positively correlated with storage root yield. Analysis of the relationship between storage root length: girth ratio under no irrigation, irrigation and combined analysis gave a negative slope (Fig. 2). The coefficients of determination $\left(\mathrm{r}^{2}\right)$ were 0.25 under irrigation, 0.13 under no irrigation and 0.30 in the combined analysis.

\section{Performance of genotypes}

Significant differences $(P<0.05)$ in storage root yield were observed for genotypes at the different harvesting times under irrigation and no irrigation (Table 4). Mean storage root yields at six MAP for all genotypes were 10.54 and $10.91 \mathrm{t} /$ ha under irrigation and no irrigation, respectively. Genotype 96/1708 had the highest storage root yield (19.25 t/ha) under irrigation, whilst CTSIA 48 had the lowest $(7.0 \mathrm{t} / \mathrm{ha})$. Under no irrigation, root yield ranged between 7.5 and $17.0 \mathrm{t} /$ ha for Biabasse and $96 / 1708$, respectively. Mean storage root yield under irrigation increased to $14.47 \mathrm{t} /$ ha at $8 \mathrm{MAP}$, whilst under no irrigation, it only increased to $12.28 \mathrm{t} / \mathrm{ha}$. Storage root yields varied from $10.17 \mathrm{t} /$ ha for CTSIA 48 to $22.25 \mathrm{t} /$ ha for $96 / 1708$ under irrigation. Under no irrigation, root yields ranged between 9.08 and 18.0 t/ha for CTSIA 48 and $96 / 1708$, respectively. Storage root yield rankings of genotypes changed at 10 MAP under irrigation and no irrigation. The highest root yield $(25.67 \mathrm{t} / \mathrm{ha})$ under irrigation was obtained from 00/0203 with CTSIA 48 giving the lowest root yield (12.08 t/ha). Under no irrigation, $96 / 1708$ had the highest storage root yield of $19.67 \mathrm{t} / \mathrm{ha}$ whilst CTSIA 48 had the lowest $(11.42 \mathrm{t} / \mathrm{ha})$ at $10 \mathrm{MAP}$.

Average storage root yields at 12 MAP were 16.39 and $26.58 \mathrm{t} /$ ha under no irrigation and irrigation, respectively. Five genotypes (96/1708, I91934, TME 419, 00/0203 and UCC2001/449) had significantly higher storage root yield than the best local farmer preferred variety, Pontisange, under irrigation. Two genotypes, 191934 and UCC2001/449, also had significantly higher storage root yield than Pontisange under no irrigation. Genotype 96/1708 had the highest root yield under irrigation (38.25 t/ha), whilst CTSIA 48 had the lowest yield (19.0 t/ ha). Under no irrigation, I91934 had the highest yield (21.67 t/ha) and CTSIA 48 had the lowest (11.08 t/ha).

\section{Pattern of fresh storage root yield and dry matter accumulation in roots}

There was an increase in root bulking during the course of the experiment (Fig. 3). Storage root bulking rate was slow under no irrigation when compared with the rate under irrigation. There was only a marginal increase in mean storage root yield from 8 MAP to 12 MAP under no irrigation. Storage root dry matter content (\%) was fairly stable under irrigation but declined sharply from 8 MAP to 12 MAP under no irrigation (Fig. 4).

\section{Relationships between storage root yield at different harvests and final root yield (12 MAP)}

High phenotypic correlations were observed between storage root yields at different harvest times and the final storage root yields under no irrigation and under irrigation. The strongest correlation with final root yield under no irrigation was storage root yield at $10 \mathrm{MAP}$ (Fig. 5). A large proportion of the dry matter obtained at the final harvest under stress was dependent on what was accumulated during the first few months (6-8 MAP) before the stress period. However, storage root yield at 12 MAP under no irrigation depended more on the yield at 10 MAP $\left(\mathrm{r}^{2}=0.8\right)$. However, under irrigation, storage root yield at final harvest depended on the entire activities by the plants before the final harvest. Significant genotypic variations were again observed in the rate of storage root bulking when storage root yield at the different harvests was expressed as a percentage 


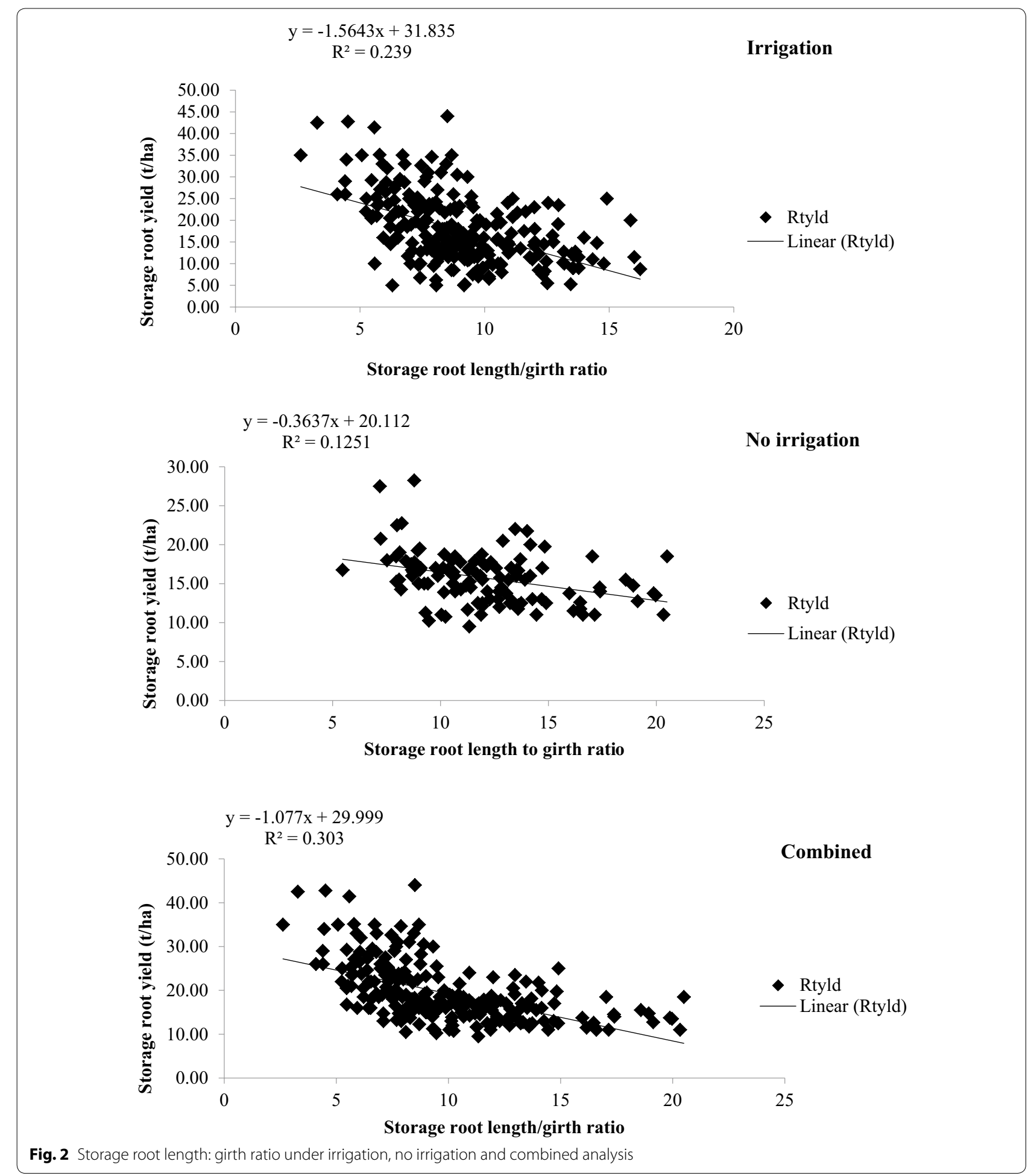

of the final storage root yield at 12 MAP under irrigation and under no irrigation (Table 5). At 6 months after planting, most of the genotypes had accumulated more than $50 \%$ of their final storage root yield at 12 MAP under no irrigation but only four genotypes (96/1708,
CTSIA 110, CTSIA 230 and TME 435) had produced $50 \%$ or more of their final storage root yield under irrigation. At six MAP, genotype 96/1708 had accumulated 55.8 and $81 \%$ of its final root yield under irrigation and no irrigation, respectively. 
Table 4 Storage root yield (t/ha) of 20 cassava genotypes at different harvest times under irrigation and no irrigation

\begin{tabular}{|c|c|c|c|c|c|c|c|c|}
\hline \multirow[t]{3}{*}{ Genotypes } & \multicolumn{8}{|c|}{ Storage root yield (t/ha) } \\
\hline & \multicolumn{2}{|c|}{$6 \mathrm{MAP}$} & \multicolumn{2}{|c|}{8 MAP } & \multicolumn{2}{|c|}{10 MAP } & \multicolumn{2}{|c|}{12 MAP } \\
\hline & Irri & No irri & Irri & No irri & Irri & No irri & Irri & No irri \\
\hline 00/0203 & 9.08 & 11.67 & 14.50 & 12.17 & 25.67 & 15.50 & 33.56 & 16.00 \\
\hline $96 / 1708$ & 19.25 & 17.00 & 22.25 & 18.00 & 24.33 & 19.67 & 38.25 & 20.75 \\
\hline $96 / 409$ & 10.33 & 12.75 & 15.42 & 13.50 & 18.67 & 15.33 & 28.42 & 17.46 \\
\hline ATR 002 & 9.42 & 8.67 & 12.50 & 11.50 & 16.92 & 15.42 & 25.33 & 16.50 \\
\hline ATR 007 & 9.42 & 8.42 & 12.25 & 10.92 & 15.58 & 13.00 & 23.08 & 13.38 \\
\hline Biabasse ${ }^{a}$ & 7.75 & 7.50 & 11.42 & 9.92 & 17.33 & 12.92 & 23.50 & 14.33 \\
\hline CTSIA 110 & 12.17 & 8.42 & 13.83 & 11.17 & 15.50 & 14.00 & 21.50 & 14.72 \\
\hline CTSIA 112 & 10.83 & 11.25 & 13.83 & 13.33 & 15.75 & 15.58 & 26.42 & 16.17 \\
\hline CTSIA 230 & 10.83 & 10.60 & 14.83 & 11.42 & 15.92 & 13.50 & 21.67 & 14.58 \\
\hline CTSIA 45 & 8.83 & 9.67 & 13.75 & 10.60 & 17.92 & 12.50 & 25.63 & 14.58 \\
\hline CTSIA 48 & 7.00 & 7.67 & 10.17 & 9.08 & 12.08 & 11.42 & 18.29 & 11.08 \\
\hline CTSIA 65 & 8.50 & 9.92 & 10.92 & 11.33 & 14.67 & 12.42 & 20.46 & 13.42 \\
\hline CTSIA 72 & 7.67 & 8.08 & 11.42 & 9.34 & 16.42 & 12.24 & 20.75 & 14.96 \\
\hline 191934 & 12.83 & 11.17 & 20.83 & 13.83 & 25.50 & 18.83 & 37.42 & 21.67 \\
\hline MM 96/1751 & 10.75 & 12.83 & 14.67 & 14.75 & 23.42 & 16.92 & 29.29 & 19.97 \\
\hline NWA 004 & 8.75 & 12.50 & 12.83 & 13.27 & 17.50 & 15.00 & 21.75 & 15.96 \\
\hline Ponstisange $e^{a}$ & 8.58 & 11.42 & 12.75 & 14.02 & 18.33 & 15.62 & 25.50 & 16.83 \\
\hline TME 419 & 11.83 & 11.42 & 18.42 & 13.17 & 22.08 & 16.25 & 33.54 & 17.50 \\
\hline TME 435 & 14.83 & 12.83 & 18.00 & 13.33 & 20.00 & 14.67 & 29.50 & 15.75 \\
\hline UCC 2001/449 & 12.17 & 13.33 & 14.83 & 14.58 & 24.08 & 17.50 & 33.38 & 21.25 \\
\hline Mean & 10.54 & 10.91 & 14.47 & 12.28 & 18.88 & 14.91 & 26.58 & 16.34 \\
\hline SED & 1.07 & 0.88 & 1.09 & 1.07 & 1.66 & 0.85 & 2.98 & 2.11 \\
\hline $\mathrm{t}$ (cal)(means) & NS & & 2.33 & & 3.90 & & 7.45 & \\
\hline$t_{0.05(2), 38}$ & 2.02 & & 2.02 & & 2.02 & & 2.02 & \\
\hline
\end{tabular}

a Local farmer-preferred varieties, NS not significant $(P=0.706)$, Irri, irrigation; No irri, no irrigation

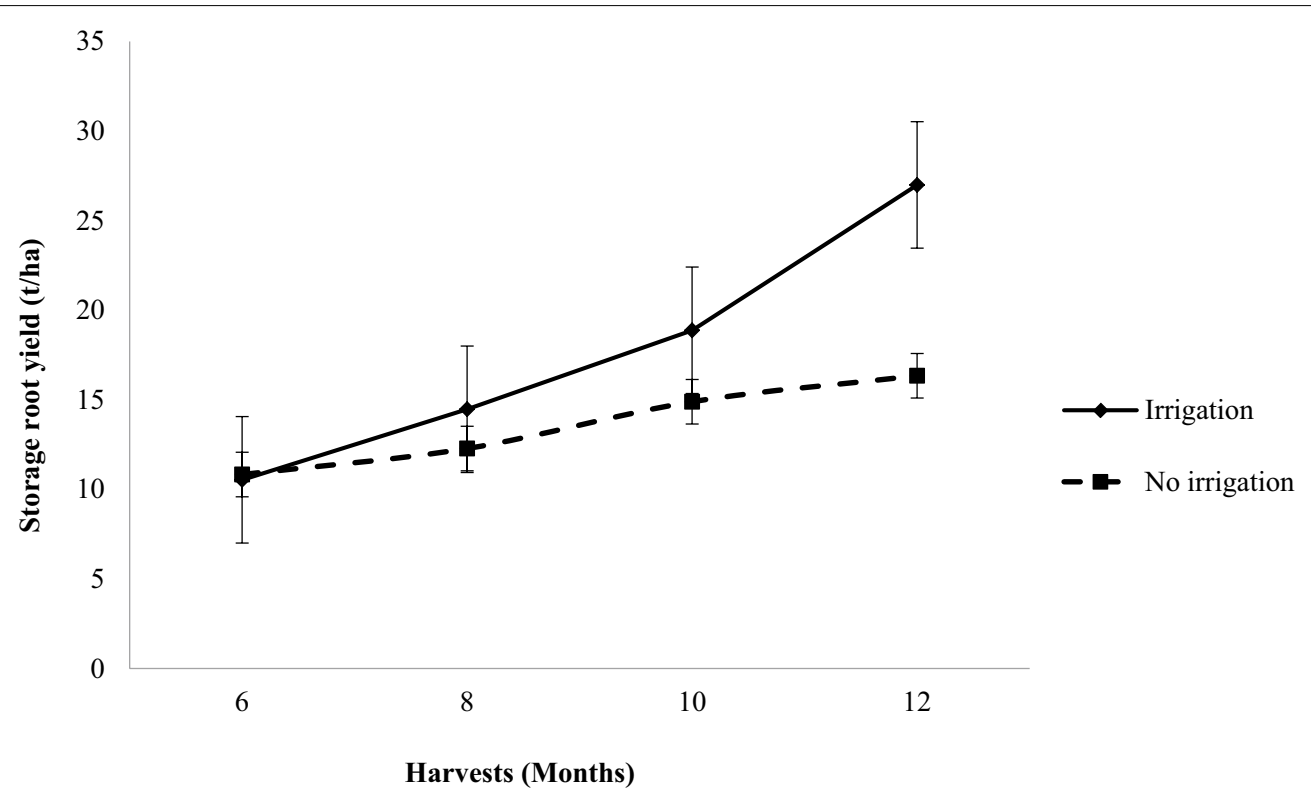

Fig. 3 Storage root bulking trend from 6 to 12 months after planting under irrigation and no irrigation 


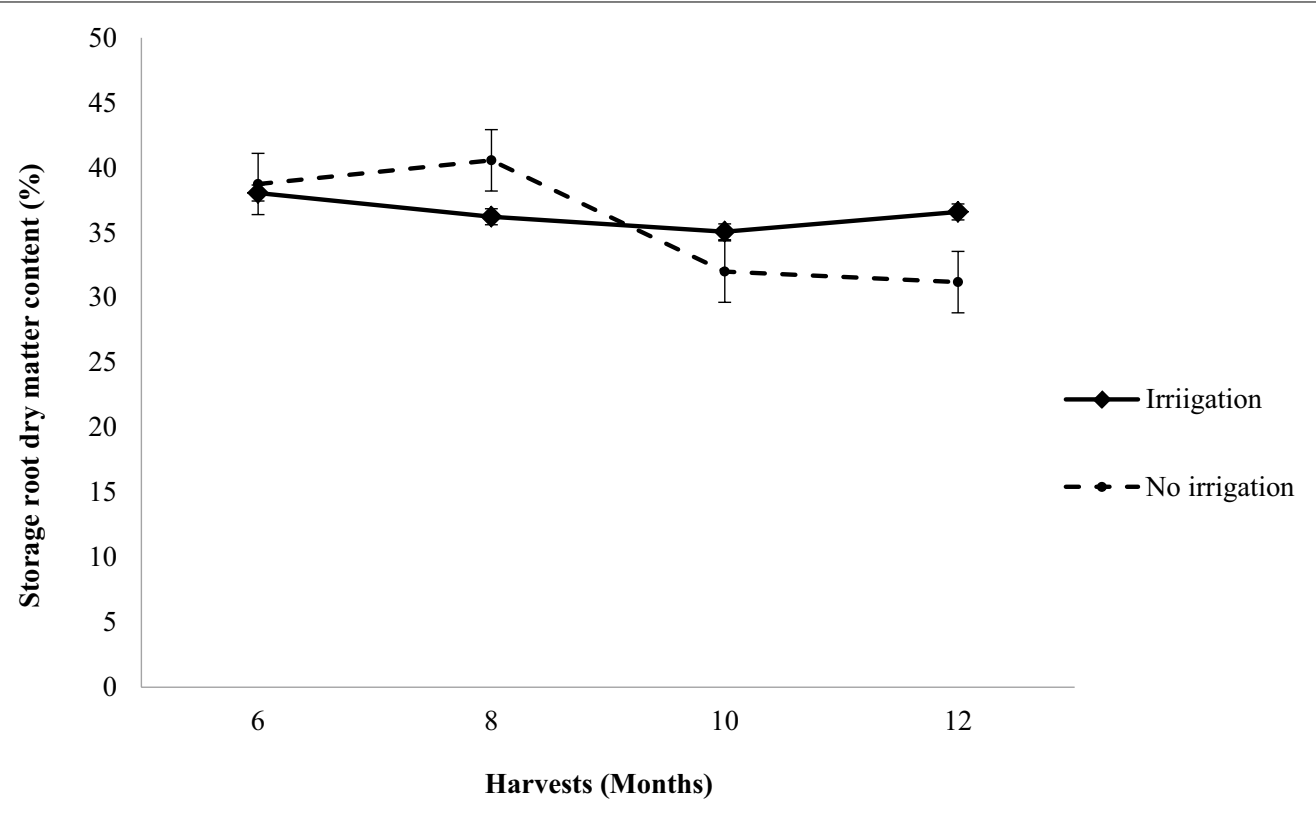

Fig. 4 Average storage root dry matter content at different harvest times under irrigation and no irrigation

\section{Discussion}

\section{Pattern of storage root bulking}

According to El-Sharkawy [4], cassava plants begin root bulking at 90 days after planting but roots become a major sink only between 180 and 300 days after planting. The cassava plant is naturally a perennial shrub and can grow indefinitely alternating periods of vegetative growth and root bulking [7]. However, the rate of storage root bulking in cassava varies over a long period due to prevailing changes in the environmental conditions [9]. The application of irrigation facilitated continuous accumulation of dry matter in the storage roots, which was not the case in the no irrigation plots. The rate of average dry matter accumulation was lower in the stressed plots, which confirms similar observations made by Bitai and Lian [26] in sweet potato. They found that early-maturing cultivars rapidly initiated storage roots development, thereby reaching their maximum yield within a short growing period. They also indicated that the bulking rate of storage roots of early-maturing cultivars declines in the early (or later) period of growth, whereas for the latematuring cultivars, the bulking rate increases at the middle and later growth periods. Therefore, environmental conditions that curtail storage root bulking will adversely affect late-bulking genotypes compared with early-bulking genotypes due to their differential sink-source relationships at the different stages in their phenology [21]. Though most crops have specific phases in their phenology that can be targeted for improvement against drought, it has not been easy to do so for cassava due to differential partitioning of dry matter into the above ground biomass and roots [4, 7]. High-yielding cassava cultivars have a high bulking rate over a long period of time, whereas cultivars with intermediate and low storage root yield have a low bulking rate of shorter duration or lower bulking rate for longer duration [17, 23].

Differential response of genotypes in storage root bulking was observed in this study, resulting in crossover interactions as some genotypes that had lower yield at 6 months had higher yield at 12 months than most of the ones that showed good yield at 6 months. This observation was contrary to the prediction by Hershey [23] and Okogbenin et al. [17] who indicated that productivity in cassava at six MAP can be used as a criterion to screen for high-yielding cassava varieties because early fresh storage root yielders are the higher yielders at later stages of growth. Genotypes that had low storage root yield at 6 months but high yield at 12 MAP might have used the above ground part as the major sink before partitioning materials into storage roots. El-Sharkawy [4] reported that distribution of carbohydrates to the different organs of cassava changes during the growth cycle, with the shoot being the major sink during the first 5 months and storage roots the major sink later. Previous study by Adjebeng-Danquah et al. [19] indicated that genotypes that partitioned dry matter production into storage roots earlier than others were able to bulk over $60 \%$ of their final storage root yield by 6 months after planting.

Okogbenin and Fregene [11] linked high early storage root yield to genotypic variability in the rate of storage 


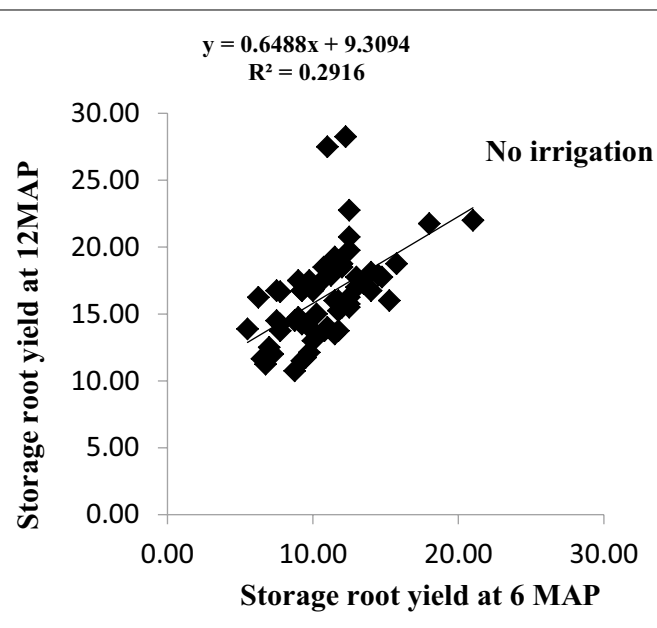

$\mathbf{y}=\mathbf{1 . 0 1 8 4 x}+16.259$
$\mathbf{R}^{2}=0.2992$
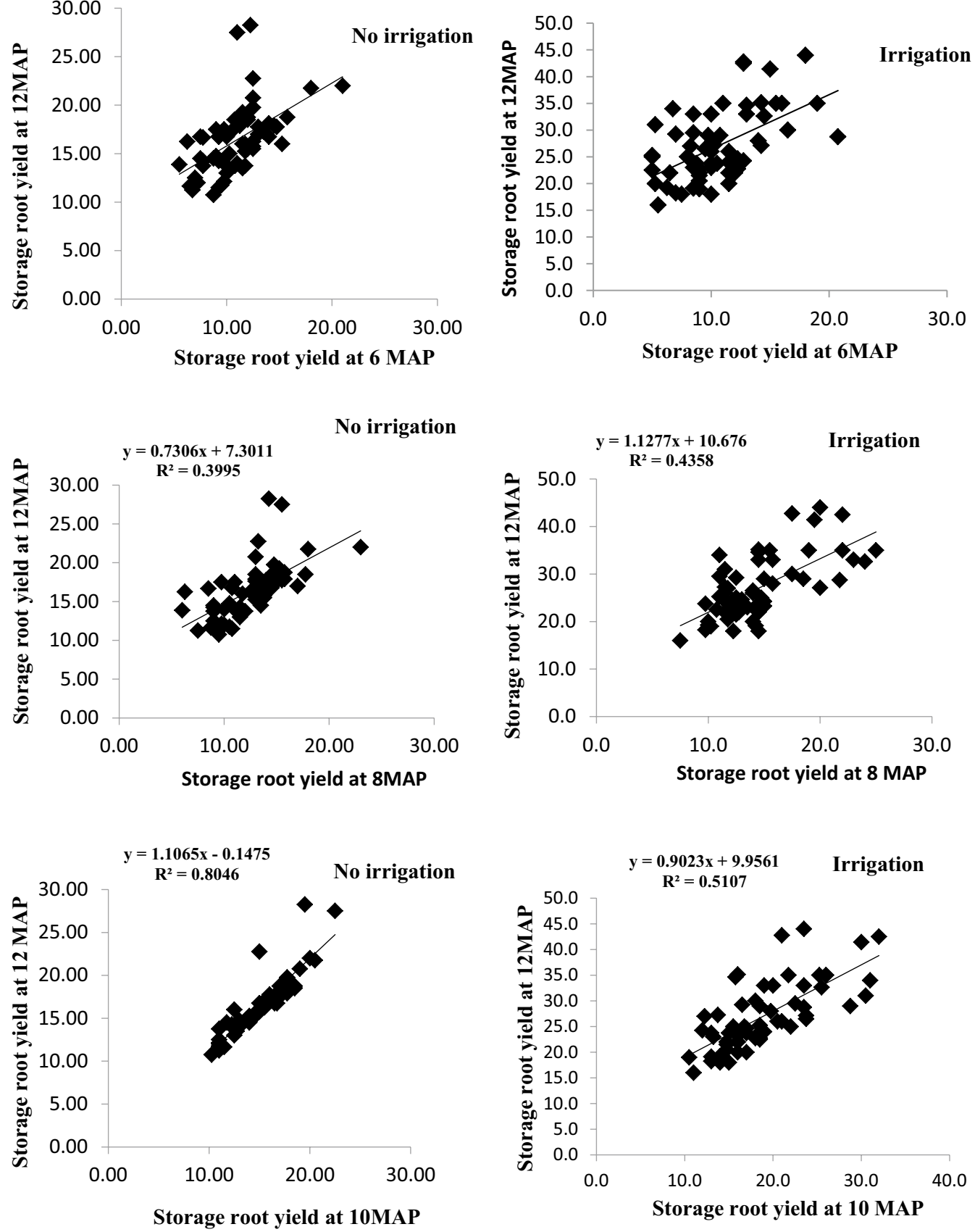

Fig. 5 Relationships between storage root yield at different harvests and root yield at 12 MAP under no irrigation and irrigation

root bulking. Fast bulking genotypes begin storage root development and shoots simultaneously, which varies from those of late- or slow-bulking genotypes, which develop sufficient above ground biomass before storage root bulking commences [4, 7]. Suja et al. [27] also indicated that differences in bulking rate and the period
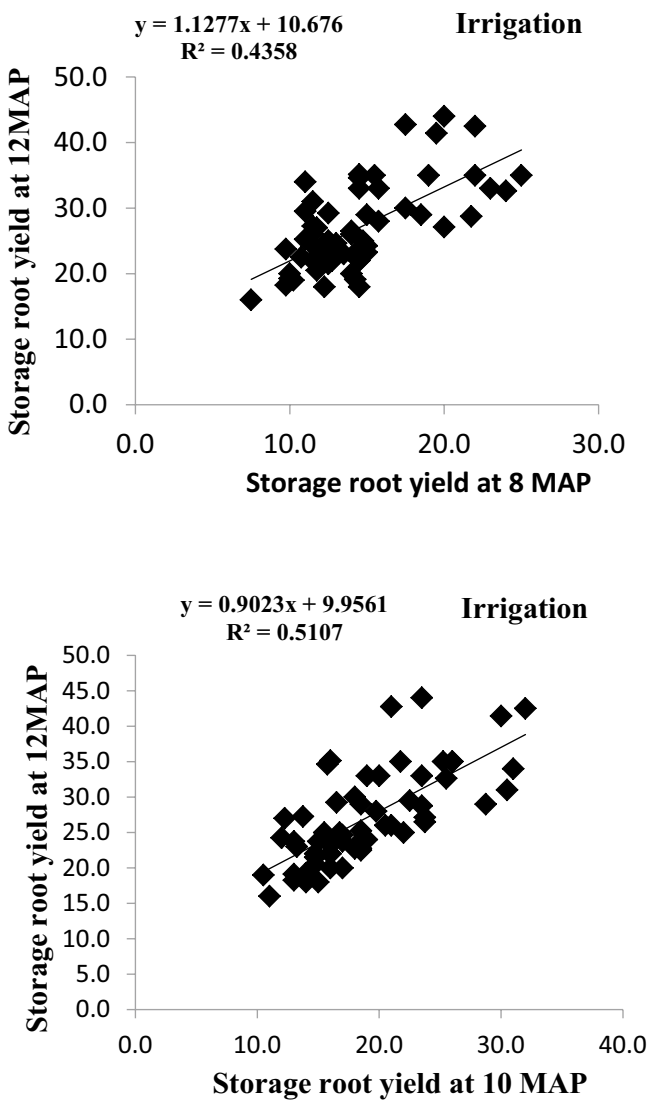

over which bulking lasts are responsible for differences in high- and low-yielding cassava cultivars. Early-maturing genotypes exhibit maximum bulking rate during their early growth stages compared with late-maturing genotypes. This pattern depends on the growth conditions, particularly moisture, which may affect the choice of sink 
Table 5 Storage root yield as percentage of final storage root yield at 12 MAP under irrigation and no irrigation

\begin{tabular}{|c|c|c|c|c|c|c|}
\hline \multirow[t]{3}{*}{ Genotypes } & \multicolumn{6}{|c|}{$\%$ of storage root yield at 12 MAP } \\
\hline & \multicolumn{2}{|l|}{6 MAP } & \multicolumn{2}{|l|}{8 MAP } & \multicolumn{2}{|c|}{10 MAP } \\
\hline & Irri & No irri & Irri & No irri & Irri & No irri \\
\hline 00/0203 & 25.70 & 73.10 & 42.31 & 76.20 & 75.74 & 95.66 \\
\hline $96 / 1708$ & 55.80 & 81.00 & 64.20 & 85.91 & 69.81 & 95.05 \\
\hline $96 / 409$ & 36.30 & 72.80 & 53.70 & 77.11 & 64.51 & 87.47 \\
\hline ATR 002 & 36.80 & 52.50 & 49.11 & 68.05 & 65.9 & 93.09 \\
\hline ATR 007 & 41.00 & 64.00 & 53.41 & 81.71 & 67.78 & 96.95 \\
\hline Biabasse $^{a}$ & 33.50 & 53.20 & 49.80 & 70.21 & 75.91 & 90.06 \\
\hline CTSIA 110 & 54.60 & 58.40 & 62.30 & 77.50 & 70.27 & 95.24 \\
\hline CTSIA 112 & 40.60 & 69.90 & 52.60 & 82.51 & 60.07 & 96.31 \\
\hline CTSIA 230 & 50.00 & 74.04 & 70.41 & 78.92 & 73.95 & 92.25 \\
\hline CTSIA 45 & 37.10 & 65.81 & 57.32 & 72.20 & 74.81 & 85.40 \\
\hline CTSIA 48 & 37.10 & 65.50 & 52.90 & 77.40 & 63.69 & 94.24 \\
\hline CTSIA 65 & 40.20 & 74.50 & 52.71 & 84.80 & 71.00 & 92.79 \\
\hline CTSIA 72 & 34.90 & 59.90 & 51.12 & 63.90 & 72.65 & 91.03 \\
\hline 191934 & 33.10 & 53.31 & 54.10 & 65.50 & 65.21 & 87.65 \\
\hline MM 96/1751 & 39.90 & 65.20 & 54.01 & 75.20 & 86.25 & 86.20 \\
\hline NWA 004 & 38.20 & 78.41 & 56.13 & 83.09 & 76.72 & 93.96 \\
\hline Pontisange ${ }^{\mathrm{a}}$ & 34.70 & 68.51 & 52.40 & 81.31 & 72.61 & 91.64 \\
\hline TME 419 & 35.40 & 65.60 & 55.21 & 74.90 & 65.96 & 92.61 \\
\hline TME 435 & 51.80 & 81.70 & 62.40 & 84.70 & 69.00 & 93.20 \\
\hline UCC 2001/449 & 34.90 & 66.60 & 42.61 & 72.21 & 69.62 & 84.98 \\
\hline Mean & 39.58 & 67.20 & 54.44 & 75.68 & 70.57 & 91.79 \\
\hline SED & 6.12 & 10.40 & 8.42 & 12.56 & 11.23 & 12.65 \\
\hline $\mathrm{t}$ (cal)(means) & 10.56 & & 8.24 & & 13.68 & \\
\hline$t_{0.05(2), 38}$ & 2.024 & & 2.024 & & 2.024 & \\
\hline
\end{tabular}

a Local farmer-preferred varieties; Irri, irrigation; No irri, no irrigation

$[4,20]$. Different plant organs are affected differentially by stress conditions and could show different trends $[28$, 29].

The pattern of storage root development in this study varied among the genotypes under irrigation and no irrigation as shown by the trend in the storage root length: girth ratio. The pattern of storage root bulking under the different conditions indicates that in cassava, dry matter is partitioned for root elongation compared to expansion under stress. This corroborates the findings of ElSharkawy et al. [30] who reported that cassava extends its roots to lower soil depths for moisture extraction under stress conditions. Storage root length: girth ratio was found to be negatively correlated with storage root yield, indicating that elongation of storage roots to lower depths could be detrimental to yield. This presupposes that the amount of photosynthates utilised for storage root growth was not as important as the pattern of accumulation, whether for elongation or for expansion in girth. Since the storage roots of cassava represent the economic part, utilisation of the photosynthates for storage root expansion will be more beneficial for storage root yield. However, the significant genotypic variation observed for this trait means that genotypes with good partitioning efficiency for storage root expansion could be selected for further improvement. Though deeper storage roots may be good adaptation for survival under drought conditions in other crops [31-33], it could be detrimental in cassava if expansion in storage root girth is compromised. Root growth exhibits positive hydrotropism and gravitropism, therefore, there is a natural tendency for storage root extension to prevail over expansion due to the need to explore lower soil depths for moisture [21, 34]. The results of this study indicated that even though severe yield losses in cassava may occur due to moisture stress [22, 35, 36], genotypic variation exists in the extent of reduction due to variations in the pattern of photosynthesis accumulation.

\section{Conclusion}

Genotypes exhibited different storage root bulking patterns under irrigation and no irrigation. Genotype 
96/1708 that had the highest yields from 6 MAP till 12 MAP is early bulking and can be a strong candidate for adaptation to the short rainy season of the Guinea savannah ecology. According to the findings of this study, genotypes that utilised photosynthates for storage root extension instead of expansion in storage root girth can survive under the drought conditions but root yield may be compromised. Significant genotypic variability exists for ratio of storage root length to storage root girth; therefore, it can be used as an index for selecting genotypes with the natural affinity for expansion is storage root girth even under limited moisture. Five genotypes (96/1708, 00/0203, I91934, UCC2001/449 and TME 419) produced storage root yields that were higher than the better widely cultivated local farmer-preferred variety (Pontisange) under irrigation, whereas two genotypes (I91934 and UCC2001/449) had better yields than the farmer preferred variety (Pontisange) no irrigation. These should be further tested to determine their broad adaptability and yield stability.

\begin{abstract}
Abbreviations
AGRA: Alliance for a Green Revolution in Africa; CIAT: International Center for Tropical Agriculture; $\mathrm{Cm}$ : centimetres; CSIR: Council for Scientific and Industrial Research; fig: figure; g: gram; IITA: International Institute of Tropical Agriculture; m: metres; MAP: months after planting; mm: millimetre; SED: standard error of the difference; $t /$ ha: tons per hectare; $1 / h$ : litres per hour.
\end{abstract}

\section{Authors' contributions}

JAD is the principal investigator. VEG, SKO, IKA and JMA were the academic supervisors of the PhD Thesis research of the principal investigator. They provided technical advice in formulation of the research objectives, conducting the experiment and the review of the write up. All authors read and approved the manuscript.

\section{Author details}

${ }^{1}$ CSIR-Savanna Agricultural Research Institute, P. O. Box TL 52, Tamale, Ghana. ${ }^{2}$ Cornell University, Ithaca, NY, USA. ${ }^{3}$ West Africa Centre for Crop Improvement, University of Ghana, Legon, Ghana. ${ }^{4}$ Department of Botany, University of Ghana, Legon, Ghana. ${ }^{5}$ CSIR-Crops Research Institute, Kumasi, Ghana.

\section{Acknowledgements}

The authors are grateful to the Generation Challenge Programme and the Alliance for Green Revolution in Africa for sponsoring this study. The staff of the Root and Tuber Crops Improvement Sections of the CSIR-Savanna Agricultural Research Institute, Nyankpala, are duly appreciated for their assistance during the conduct of the experiment.

\section{Competing interests}

The authors declare that they have no competing interests.

Received: 17 November 2015 Accepted: 29 April 2016

Published online: 10 June 2016

\section{References}

1. Okogbenin E, Ekanayake IJ, Porto MCM. Genotypic variability in adaptation responses of selected cassava clones to drought stress in the Sudan Savannah Zone of Nigeria. J Agron Crop Sci. 2003;189:376-89.

2. El-Sharkawy MA. Physiological characteristics of cassava tolerance to prolonged drought in the tropics: implications for breeding cultivars adapted to seasonally dry and semiarid environments. Braz J Plant Physiol. 2007;19(4):257-86.

3. Hillocks RJ. Cassava in Africa. In: Hillocks RJ, Thresh JM, Bellotti A, editors. Cassava: biology, production and utilization. Wallingford: CABI; 2002. p. 41-54.

4. El-Sharkawy MA. Cassava biology and physiology. Plant Mol Biol. 2004;56:481-501.

5. El-Sharkawy MA, Cock JH. Water use efficiency of cassava, I: effects of air humidity and water stress on stomatal conductance and gas exchange. Crop Sci. 1984;24(3):497-502.

6. Ceballos H, Iglesias CA, Perez JC, Dixon AGO. Cassava breeding: opportunities and challenges. Plant Mol Biol. 2004;56:503-16.

7. Alves AAC. Cassava botany and physiology. In: Hillocks RJ, Thresh JM, Bellotti A, editors. Cassava: biology, production and utilization. Wallingford: CABl; 2002. p. 67-90.

8. Osei C. Developing early bulking cassava varieties with high yield potential. In: S.K. Asante, F.K. Padi, editors. Strategic innovations for dryland farming in Northern Ghana. Project 6 of the Challenge Program on Water and Food. Technical Report; 2005. p. 49-54.

9. Ekanayake IJ, Osiru DSO, Porto MCM. Physiology of cassava. IITA Research Guide No. 55. 3rd edition. IITA, Ibadan, Nigeria. 1998.

10. Wahid A, Gelani S, Ashraf M, Foolad MR. Heat tolerance in plants: an overview. Env Exp Bot. 2007;61:199-223.

11. Okogbenin E, Fregene M. Genetic and QTL mapping of early root bulking in an $\mathrm{F}_{2}$ mapping population of non-inbred parents in cassava (Manihot esculenta Crantz). Theor Appl Genet. 2002;106:58-66.

12. Okogbenin E, Marin J, Fregene M. QTL analysis for early yield in a pseudo $F_{2}$ population of cassava. Afr J Biotechnol. 2008;7(2):31-138.

13. Annor-Frempong C. A survey of cassava cultivation practices in Ghana. Acta Hort (ISHS). 1994;380:216-21.

14. Nweke FI, Dixon AGO, Asiedu R, Folayan SA. Cassava varietal needs of farmers and potential for production and growth in Africa. Collaborative Study of Cassava in Africa (COSCA). IITA, Ibadan, Working paper No. 10. 1994.

15. Okechukwu RU, Dixon AGO. Performance of improved cassava genotypes for early bulking, disease resistance, and culinary qualities in an inland valley ecosystem. Agron J. 2009;101:1258-65.

16. Kamau J, Melis R, Laing M, Derera J, Shanahan P, Eliud C, Ngugi K. Farmers' participatory selection for early bulking cassava genotypes in semi-arid Eastern Kenya. J Agron Crop Sci. 2011;3:44-52.

17. Okogbenin E, Setter TL, Ferguson ME, Mutegi R, Ceballos H, Olasanmi B, Fregene M. Phenotypic approaches to drought in cassava: review. Front Physiol. 2013;4(93):1-15.

18. Legg JP, Jeremiah SC, Obiero HM, Maruthi MN, Ndyetabula I, Okao-Okuja G, Bouwmeester H, Bigirimana S, Tata-Hangy W, Gashaka G, Mkamilo G, Alicai T, Kumar LP. Comparing the regional epidemiology of the cassava mosaic and cassava brown streak virus pandemics in Africa. Virus Res. 2011;159:161-70.

19. Adjebeng-Danquah J, Acheremu K, Asante SK, Kusi F, Osei C. Evaluation of early bulking cassava accessions for high yield potential for the Guinea Savannah Zone of Ghana. Ghana J Agric Sci. 2012;45:61-70.

20. Spollen WG, LeNoble ME, Samuels TD, Bernstein N, Sharp RE. ABA accumulation maintains primary root elongation at low water potentials by restricting ethylene production. Plant Physiol. 2000;122:967-76.

21. Ober ES, Sharp RE. Regulation of root growth responses to water deficit. In: Jenks MA, Hasegawa PM, Jain SM, editors. Advances in molecular breeding toward drought and salt tolerant crops. New York: Springer; 2007. p. 33-53.

22. Wasson AP, Richards RA, Chatrath R, Misra SC, Prasad SVS, Rebetzke GJ, Kirkegaard JA, Christopher J, Watt M. Traits and selection strategies to improve root systems and water uptake in water-limited wheat crops. J Exp Bot. 2012;63:3485-98.

23. Hershey C. Cassava genetic improvement: theory and practice. Rome: FAO Publishing; 2012.

24. EPA. National Action Programme to Combat Drought and Desertification Final Report. Environmental Protection Agency Accra-Ghana. 2003.

25. Payne RW, Murray DA, Harding SA, Baird DB, Soutar DM. Genstat for Windows: Introduction. 12th ed. Hemel Hempstead: VSN International; 2009.

26. Bitai Z, Lian NP. Parents selection and its combination for early maturing high starch and high yielding sweet potato breeding. Jiangsu J Agric Sci. 1978:4:22-7. 
27. Suja G, John KS, Sreekumari J, Srinivas T. Short-duration cassava genotypes for crop diversification in the humid tropics: growth dynamics, biomass, yield and quality. J Sci Food Agric. 2009;90:188-98.

28. Atkinson NJ, Urwin E. The integration of plant biotic and abiotic stresses: from genes to the field. J Exp Bot. 2012;63:3523-44.

29. Gall HL, Philippe F, Dormon JM, Gillet F, Pelloux J, Rayon C. Cell wall metabolism in response to abiotic stress. Plants. 2015:4:112-66.

30. El-Sharkawy MA, Hernandez AD, Hershey C. Yield stability of cassava during prolonged mid-season water-stress. Exp Agric. 1992;28:165-74.

31. Duggan BL, Richards RA, van Herwaarden AF. Agronomic evaluation of tiller inhibition gene (tin) in wheat. II. Growth and partitioning of assimilate. Aust J Agric Res. 2005;56:179-86.

32. Richards RA, Watt M, Rebetzke GJ. Physiological traits and cereal germplasm for sustainable agricultural systems. Euphytica. 2007;154:409-25.
33. Manschadi AM, Hammer GL, Christopher JT, DeVoil P. Genotypic variation in seedling root architectural traits and implications for drought adaptation in wheat (Triticum aestivum L.). Plant Soil. 2008;303:115-29.

34. Serraj R, Hash TC, Buhariwalla HK, Bidinger FR, Folkertsma RT, Chandra S, Gaur PM, Kashiwagi J, Nigam SN, Rupakula A, Crouch JH. Marker-assisted breeding for crop drought tolerance at ICRISAT: achievements and prospects. In: Tuberosa R, Phillips RL, Gale M, editors. Proceedings of the International Congress "In the Wake of the Double Helix: From the Green Revolution to the Gene Revolution", 27-31 May 2003, Bologna, Italy. 2005; p. 217-38.

35. Aina OO, Dixon AGO, Akinrinde EA. Effect of soil moisture stress on growth and yield of cassava in Nigeria. Pak J Biol Sci. 2007;10(18):3085-90

36. Turyagyenda FL, Kizito EB, Baguma Y, Osiru D. Evaluation of Ugandan cassava germplasm for drought tolerance. Int J Agric Crop Sci. 2013;5(3):212-26.

\section{Submit your next manuscript to BioMed Central and we will help you at every step:}

- We accept pre-submission inquiries

- Our selector tool helps you to find the most relevant journal

- We provide round the clock customer support

- Convenient online submission

- Thorough peer review

- Inclusion in PubMed and all major indexing services

- Maximum visibility for your research

Submit your manuscript at www.biomedcentral.com/submit 